УДК 343.14

DOI https://doi.org/10.32837/pyuv.v1i4(29).391

\author{
О.В.Острогляд \\ orcid.org/0000-0003-0003-3075 \\ кандидат юридичних наук, доцент, \\ проректор з наукової роботи \\ Університету Короля Данила
}

\title{
ДОКАЗУВАННЯ В АПЕЛЯЦІЙНОМУ СУДІ (ІСТОРИЧНИЙ ЕКСКУРС)
}

Постановка проблеми. Стаття 2 Протоколу № 7 до Конвенції про захист прав людини і основоположних свобод передбачає «Кожен, кого суд визнав винним у вчиненні кримінального правопорушення, має право на перегляд судом вищої інстанції факту визнання його винним або винесеного йому вироку». Можливість перегляду рішення суду першої інстанції, що зазвичай наближений до населення, але має значно більшу завантаженість, ніж інші інстанції, дозволяє мінімізувати можливість помилок. Оскільки кожного року в апеляційному порядку закривається біля 50 кримінальних проваджень за відсутності подіі злочину чи складу злочину, а це біля 50 осіб, притягати до відповідальності яких не було підстав.

Тому чим більше гарантій постановлення законного і обгрунтованого рішення має підозрюваний, обвинувачений, засуджений, потерпілий, тим краще. I в цьому випадку роль апеляційного суду не варто применшувати.

Згідно з чинним Кримінальним процесуальним кодексом України (стаття 392) в апеляційному порядку можуть бути оскаржені судові рішення, які були ухвалені судами першої інстанції і не набрали законної сили, що дозволяє відносно оперативно усунути помилки та не допустити набрання необгрунтованим рішенням законної сили. Проте це не повторення суду першої інстанції, оскільки в такому разі втрачався б будь-який сенс існування цих інстанцій, оскільки (стаття 404 КПК) суд апеляційної інстанції переглядає судові рішення суду першої інстанції лише в межах апеляційної скарги, що скорочує процес доказування до вимог, що викладаються в ній. Відповідно, повноваження стосовно дослідження доказів визначаються переглядом кримінального провадження в межах вимог апеляційної скарги 3 урахуванням можливості прийняття рішення з виходом за межі скарги, якщо цим не погіршується становище обвинуваченого.

Та чи був притаманний такий перегляд рішень суду першої інстанції Україні завжди? I чи не має певних історичних положень, які варто переглянути і частково запозичити зараз? Відповідь на ці питання можна дати лише шляхом історичного аналізу інститутів перегляду, що діяли раніше на українських землях.
Аналіз останніх досліджень i публікацій. Питання апеляційного та інших переглядів piшень суду першої інстанції тією чи іншою мірою досліджувалося в працях таких науковців, як В. Головков, В. Маляренко, А. Разінкіна, А. Рівлін, А. Рижаков та інші. Проте їх дослідження в більшості стосувалися аналізу наявних на той час форм перегляду та не мали комплексного підходу щодо території України з урахуванням особливостей доказування в конкретний історичний період.

Постановка завдання. Метою роботи є історичний аналіз існування апеляційного перегляду рішень суду першої інстанції на території України в різні історичні періоди в аспекті доказування та побудова на підставі цього можливостей удосконалення цього інституту в сучасних умовах.

Виклад основного матеріалу. Відповідно до статті 407 Кримінального процесуального кодексу Апеляційний суд, проводячи повторне дослідження доказів, вправі залишити вирок без змін, змінити його, скасувати та постановити власний вирок, а також закрити провадження чи призначити новий розгляд в суді першої інстанції. Необхідно також підкреслити, що в апеляційному порядку рішення суду можна оскаржити лише один раз, оскільки в іншому разі це порушувало б принципи юридичної визначеності та стабільності судових рішень. Отже, суть апеляційного перегляду полягає в тому, що законність і обгрунтованість вироку перевіряється шляхом перегляду справи в порядку, аналогічному розгляду справи в суді першої інстанції.

Справедливість судового рішення неможлива без реалізації права зацікавленої особи на його перевірку іншим складом суду. Причому таким складом суду, який є колегіальним, незалежним від суду, що постановляв оскаржуване рішення, та який без відправлення справи в той самий суд може сам скасувати попереднє рішення i, дослідивши необхідні обставини справи, постановити своє, остаточне. Такий порядок перевірки судових рішень прийнято називати апеляційним. Через свою надійність він притаманний більшості країн світу і служить додатковою гарантією дотримання прав людини та уникнення судової помилки.

Інститут апеляційного перегляду був здавна відомий і в Україні. Л.О. Богословська зазначає, 
що перші спроби впровадження апеляції в судовий процес України мали місце ще в XVI столітті. Апеляційний порядок перегляду судових «декретів» - постанов закріплений у Литовському статуті 1588 року, який був провідним джерелом права протягом декількох століть [11, с. 207]. Проте вже з 1581 року діяв Головний литовський трибунал як основна апеляційна інстанція у Великому князівстві Литовському, Руському та Жемантійському (офіційна назва держави), до якого входили землі України [5, с. 12].

Процедурі доказування особливої уваги під час історичного дослідження цього періоду не приділялося. Епізодично можна знайти твердження про те, що не переглядалися обставини, що не досліджувалися місцевим судом.

Вперше в українському законодавстві інститут апеляційного перегляду найбільш детально був врегульований у «Правах, за якими судиться малоросійський народ» (1743р.), де він визначався як «правильне відкликання і перенесення з нижчого суду до вищого справи сторін, що судяться, коли одна якась 3 них вважала себе скривдженою вироком, винесеним у іï справі в цьому нижчому суді». Як сторонам у цивільному процесі, так і підсудному та потерпілому у кримінальному процесі належало право подати апеляцію на тій підставі, що судове рішення не відповідало праву і справедливості. «Права, за якими судиться малоросійський народ» визначили підстави, строки і порядок подання апеляції, порядок іiі розгляду та вирішення. Було встановлено строки подання апеляції:

- до 15 днів - на рішення сотенного суду до полкового;

- до 6 тижнів - на рішення полкового суду до Генерального суду і до Генеральної військової канцеляріі;

- до 7 днів (а за наявності поважних причин і більше) - на рішення Генерального суду до Генеральної військової канцелярії.

Перешкоджання з боку суддів у поданні обгрунтованої апеляції до вищого суду або передчасне виконання рішення (тобто до перегляду справи вищим судом) тягло скасування рішення, а особі, яка постраждала від нього, судді сплачували штраф і відшкодовували заподіяну їй шкоду. Якщо вищий суд, розглянувши апеляцію, встановив, що нижчим судом було винесено неправильний вирок, за яким підсудного засуджено до жорстокої або смертної кари, то судді підлягали такому ж покаранню. Разом з тим жорстоко каралось і подання учасниками процесу необгрунтованих апеляцій, особливо поєднаних 3 обвинуваченням суддів у винесенні вироку з мотивів користолюбства чи злоби. «Права, за якими судиться малоросійський народ» передбачали перелік обставин, за яких подання апеляції не допускалось (зокрема, якщо апелянт-підсудний добровільно зізнався в суді у вчиненні злочину), зазначалися безперечні підстави для скасування судового рішення [13, с. 150].

В цьому періоді можна стверджувати, що суд міг перевіряти не лише докази попереднього суду, на підставі чого міг винести новий вирок, а також переглядалися можливості обману, фальшування документів, підкупу свідків та інших протиправних дій.

Подальший розвиток інституту апеляційного перегляду в Україні тісно пов'язаний з впровадженням на їі землях законодавства Російської імперії, точніше, із Судовою реформою 1864 року, що передбачала створення змішаної форми кримінального процесу.

29.09.1862 року Олександром II були затверджені «Основні положення кримінального судочинства», а 20.11.1864 року видані «Судові Статути», а в їх числі «Статут кримінального судочинства» $\mathrm{i}$ «Статут про покарання, що накладалися мировими суддями» [4, с. 393].

Відповідно до названих законів судова система повинна була складатися з таких інстанцій:

- судів мирових: дільничні мирові судді, що обиралися в повітах земськими зборами (складалися з дворян і сільських багатіїв), а в містах міськими думами (складалися з дворян, купців, фабрикантів), розглядали незначні кримінальні справи (до одного року позбавлення волі) і цивільні справи (до 1000 руб.). Другою інстанцією для них був з'їзд мирових суддів повіту чи міста з участю почесних мирових суддів. Цей з'їзд і був апеляційною інстанцією, причому інстанцією, найбільш наближеною до розгляду справ в суді першої інстанції, а тому вона більше забезпечувала перевірку доказів за принципами усності і безпосередності [2, с. 34].

- судів загальних: окружні суди розглядали справи про нетяжкі злочини в складі трьох коронних суддів, а справи про тяжкі злочини - в складі трьох коронних суддів і дванадцяти присяжних засідателів. На вироки окружного суду без участі присяжних можна було приносити апеляційні скарги в судову палату, а вироки суду з участю присяжних могли бути опротестовані в Сенат лише в касаційному порядку.

Третьою касаційною інстанцією, що направляла діяльність всіх судів «у правильному і однозначному застосуванню законів», був кримінальний касаційний департамент Сенату [1, c. $274-275 ; 4$, c. $394 ; 7$, c. 49].

За законом 12.07.1889 року апеляційною інстанцією для міських судів і земських начальників став повітовий з'їзд, який складався з повітового начальника дворянства чи повітового члена окружного суду як головуючого і міських суддів як його членів. Усність і безпосередність при розгляді справ з'їздом не застосовувалась. 
Апеляційне провадження було обов'язковою стадією кримінального процесу для перегляду рішень всіх ланок судової системи (крім Правлячого Сенату), що не вступили в законну силу. Суди розглядали кримінальні справи за апеляційними скаргами і протестами колегіально. Завдання апеляційного розгляду полягало в тому, щоб надати сторонам новим розглядом справи додаткову гарантію справедливості судового вироку [8, с. 32].

Предметом апеляційного оскарження був вирок неостаточний і який не вступив в законну силу. Поняття вироку протиставляється поняттям постанови і ухвали, які можуть бути предметом приватного оскарження чи підлягають оскарженню не інакше, як разом із оскарженням вироку по суті $[12$, с. 540$]$.

Апеляційному оскарженню підлягали лише неостаточні вироки. Поняття остаточного і неостаточного вироку визначалось суттю справи, тяжкістю покарання і судом, що постановив рішення. Рішення окружного суду, постановлене 3 участю присяжних засідателів, було остаточним і скасовувалося за скаргою чи протестом лише в касаційному порядку. Виправдувальні вироки перегляду не підлягали, навіть якщо виникали нові обставини, що викривали виправданого. Всі інші рішення по суті вважалися неостаточними. Коло осіб, що мали право апеляційного оскарження, обмежувалося сторонами, тобто апеляційні скарги були вправі принести обвинувач, підсудний і цивільний позивач, і тільки в деяких випадках, як виняток, це право надавалось особам, які прямої участі в справі не приймали. Підсудному належало право оскаржити рішення суду в повному обсязі як особисто, так і через законних представників (чоловіка, жінку, батьків, опікунів) і добровільних представників за угодою [8, с. 33].

Апеляційне провадження розпочиналось із подачі скарги чи протесту в суд, що постановив рішення, але не пізніше двох тижнів з моменту проголошення вироку. У скарзі вказувалось: від кого вона подається, місце проживання скаржника, межі оскарження, мотиви, з яких оскаржується вирок, і вимоги сторони. Неповнота скарги не виключала прийняття іï до розгляду. Однією з особливостей апеляційного перегляду було те, що він здійснювався лише в межах, які вказані в скарзі чи протесті (ст. ст. 168 і 889 Статуту кримінального судочинства) [9, с. 283].

Подання апеляційної скарги чи протесту призупиняло виконання вироку, але тільки в тій його частині, яка була оскаржена. Проти скарги, поданої однією стороною, інша сторона могла подати свої заперечення чи пояснення обов'язковому члену мирового з'їзду (якщо справа розглядалася мировим суддею) і в судову палату (при оскарженні рішень загальних судових ухвал), куди передавалась і сама справа для апеляційного розгляду.
Процедура апеляційного розгляду була схожою до порядку розгляду справи у мирового судді, але мала певні особливості. Відсутність сторін не була перешкодою для розгляду справи. Виняток складали випадки обов'язкової участі обвинуваченого в справах, за які як покарання було передбачено тюремне ув'язнення [2, с. 36].

Апеляційний перегляд був значною мірою позбавлений усності і безпосередності. Присутність обвинуваченого не була обов'язковою, допит свідків і експертів був різко обмежений. У результаті цього апеляційний перегляд у більшості справ, особливо в судових палатах, зводився до доповіді членом суду письмових актів справи і до дебатів сторін, якщо такі були присутні. Дебати ж не виходили за межі скарги чи протесту (ст. ст. 164, 888,889 CKC) [9, с. 283].

Під час постановлення рішення апеляційна інстанція не могла вийти за межі апеляційних вимог. Якщо вирок був оскаржений державним обвинувачем (чи приватним), то апеляційна інстанція могла відмінити рішення тільки відносно тих підсудних, які вказані в скарзі чи протесті. Якщо скарга подавалась тільки деякими з підсудних у справі, то апеляційна інстанція була не вправі пом'якшити покарання тим підсудним, що скарги не подавали. Розглянувши справу і заново дослідивши її юридичну і фактичну сторони, апеляційний суд приймав рішення: затверджував вирок суду першої інстанції чи постановляв новий вирок. Апеляційна інстанція не мала права повернути справу до суду, що розглядав ії̈ в першій інстанції [2, с. 37].

Декретом РНК УСРР «Про суд» від 14.11.1919 р. апеляційний перегляд як такий, що затягує процес, було замінено касаційним.

Апеляційне провадження на території України як незалежної держави було введено Законами від 21 червня і 12 липня 2001 року «Про внесення змін до Кримінально-процесуального кодексу України», якими було суттєво змінено порядок перегляду судових рішень [3].

Апеляційний перегляд рішень суду першої інстанції у кримінальних справах - одна з контрольних стадій, покликана служити посиленню гарантій правосуддя, конституційних прав і законних інтересів особи, що бере участь у кримінальному судочинстві.

Апеляційний перегляд рішень суду першої інстанції характеризується свободою оскарження сторонами. Це означає, що судові рішення можуть бути оскаржені сторонами у вищестоящий суд [10, с. 5].

Інститут апеляційного оскарження кримінальних справ дозволяе, по суті, з новим дослідженням доказів в суді вищестоящої інстанції, а не лише на основі письмових матеріалів, як в касаційному порядку, перевірити законність, 
обгрунтованість і справедливість вироку чи постанови, що винесені судом першої інстанції, з правом їх заміни новим рішенням, в тому числі і тим, що погіршує становище підсудного, яке прийняте на основі безпосереднього аналізу фактів і обставин справи [8, с. 4].

Введення в Кримінально-процесуальний кодекс України нового інституту - апеляційного перегляду рішень суду першої інстанції - можна розцінювати, безумовно, як позитивний крок.

Це твердження характеризують і такі риси апеляції:

- апеляційне провадження - це самостійна стадія кримінального процесу, що передує касаційному перегляду судових рішень;

- апеляційна інстанція розглядає справу по суті, що тягне за собою можливість постановлення нею нового рішення, яке повністю чи частково змінює вирок суду першої інстанції;

- апеляційний перегляд поєднує в собі розгляд справи по суті і касаційне провадження (оскільки є переглядом рішень місцевих судів);

- апеляція подається на вирок, постанову, ухвалу суду першої інстанції, які ще не набрали законної сили;

- кримінальна справа передається на розгляд вищестоящого суду;

- подача апеляції обгрунтовується апелянтом підставами до скасування чи зміни судового рішення;

- розглядаючи справу, апеляційний суд перевіряє юридичну і фактичну сторони справи в тому ж обсязі, що і суд першої інстанції;

- виконання рішення, постановленого судом першої інстанції і оскарженого в апеляційний суд, зупиняється;

- повноваження апеляційного суду під час розгляду справи обмежені межами апеляції і предметом рішення суду першої інстанції;

- нові вимоги, які не подавалися в суді першої інстанції, не можуть бути заявлені в апеляційному провадженні;

- за необхідності апеляційний суд проводить слідство в повному обсязі і може винести вирок [6, с. 210-211].

Позитивність уведеного інституту має прояв у тому, що, на відміну від касаційної інстанції за КПК 1960 року, суд апеляційної інстанції вправі постановити свій вирок, скасувавши чи змінивши при цьому вирок суду першої інстанції, він вправі провести судове слідство з питань, що піднімаються в скарзі чи поданні, а також у тому, що скарга чи подання подаються на рішення, які не набрали законної сили, і це надає правосуддю більш ефективного характеру.

Кримінальне процесуальне законодавство, що було оновлено в 2012 році, зберегло повною мірою інститут апеляційного оскарження, що тепер регулюється главою 31 Кримінального процесуального кодексу України «Провадження в суді апеляційної інстанції» .

Висновки. На підставі короткого історичного екскурсу можна зробити короткі висновки: загальним для процесу доказування в апеляційному порядку є те, що положення, які не досліджувалися в суді першої інстанції, не переглядаються, за винятком тих, де учасники заявляли про це клопотання під час попереднього розгляду місцевим судом, або вони стали відомі після ухвалення судового рішення; процес доказування обмежується апеляційними вимогами (хоча історично були i моменти повного перегляду); цікавим є момент заборони оскарження певних рішень, а також покарання суддів за постановлення необгрунтованих рішень, що передбачали суворе покарання, що частково можна запозичити і зараз.

\section{Jimepamypa}

1. Викторский С.И. Русский уголовный процесс. Учебное пособие / Викторский С.И. Москва : Юридическое бюро «Городець», 1997. $448 \mathrm{c.}$

2. Головков В.Л. Апелляционное производство по уголовным делам в Российской Федерации [Электронный ресурс]: Проблемы и пути решения: Дис... канд. юрид. наук: 12.00 .09 / В. Л. Головков. Москва : РГБ. 2005.

3. Закон України «Про внесення змін до Кримінально-процесуального кодексу України" від 21.06.2001 р. № 2533-111. Відомості Верховної Ради. 2001. № 34-35. ст. 187.

4. Курс советского уголовного процесса. Общая часть / [под ред. Бойкова В. А., и И.И. Корица]. Москва : «Юрид. лит», 1989.640 с.

5. Маляренко В. Кримінально-процесуальне законодавство України: питання становлення і розвитку. Право України. 2003. № 9. С. 3-14.

6. Острогляд О.В. Апеляція - новий інститут захисту прав людини в кримінальному судочинстві. Актуальні проблели вдосконалення чинного законодавства Украӥни. Збірник наукових статей. 2002. Випуск Х. С. 210-213.

7. Победкин А.В. Апелляционное производство в уголовном процессе России: Проблемы становления. Государство и право. 2001. № 3. С. 46-50.

8. Разинкина А. Н. Апелляция в уголовном производстве. Москва : Издательство «Юрлитинформ», 2004. $160 \mathrm{c}$.

9. Ривлин А.Л. Пересмотр приговоров в СССР. Москва : Госюриздат, 1958. 311 с.

10. Рыжаков А.П. Кассационное прозводство А.П. Рыжаков, А.И. Сергеев. Москва : Информ. - изд. дом «Филинъ», 1997. 128 с. (Уголовный процесс на практике).

11. Судова реформа в Україні: проблеми і перспективи: Матеріали наук, практ. конф., 18-19 квітня 2002 р., м. Харків / [Ред. кол.: Сташис В. В. (Голов, ред.) та ін.]. К; Харків : Юрінком Інтер, 2002. 288 с.

12. Фойницкий И.Я. Курс уголовного судопроизводства. В 2-х томах. Т 2. Санкт-Петербург : Издательство «АЛЬФА», 1996.606 с.

13. Шумило М.Є. Нова форма досудового розслідування - гарантія права обвинуваченого на кваліфікований захист. Матеріали Міжнар. наук, практ. семінару «Право обвинуваченого на кваліфікований захист та його забезпечення» (1-2 грудня 2005 р.). Харків, 2005. C. $26-30$. 


\section{Анотація}

Острогляд О. В. Доказування в апеляційному суді (історичний екскурс). - Стаття.

Метою статті $€$ історичний аналіз існування апеляційного перегляду рішень суду першої інстанції на території України в різні історичні періоди в аспекті доказування та побудова на підставі цього можливостей удосконалення цього інституту в сучасних умовах. Дослідження присвячено аналізу в історичному ракурсі інституту апеляційного перегляду рішень суду першої інстанції. Викладаються основні положення розвитку апеляції на території України. Зазначається, що інститут апеляційного перегляду був притаманний українським землям здавна, а інститут касації як друга інстанція був тимчасовим явищем. Аналізуються особливості доказування, що зумовлені саме цією стадією судочинства. 3'ясовано, що справедливість судового рішення неможлива без реалізації права зацікавленої особи на його перевірку іншим складом суду. Причому таким складом суду, який є колегіальним, незалежним від суду, що постановляв оскаржуване рішення, та який без відправлення справи в той самий суд може сам скасувати попереднє рішення i, дослідивши необхідні обставини справи, постановити своє, остаточне. Такий порядок перевірки судових рішень прийнято називати апеляційним. Через свою надійність він притаманний більшості країн світу і служить додатковою гарантією дотримання прав людини та уникнення судової помилки. Наголошено, що подання апеляційної скарги чи протесту призупиняло виконання вироку, але тільки в тій його частині, яка була оскаржена. Проти скарги, поданої однією стороною, інша сторона могла подати свої заперечення чи пояснення обов'язковому члену мирового з'їзду (якщо справа розглядалася мировим суддею) і в судову палату (при оскарженні рішень загальних судових ухвал), куди передавалась і сама справа для апеляційного розгляду. Зроблено висновок, що загальним для процесу доказування в апеляційному порядку є те, що положення, які не досліджувалися в суді першої інстанції, не переглядаються, за винятком тих, де учасники заявляли про це клопотання під час попереднього розгляду місцевим судом, або вони стали відомі після ухвалення судового рішення, а також процес доказування обмежується апеляційними вимогами (хоча історично були і моменти повного перегляду).

Ключові слова: суд, апеляційний перегляд, доказування, апеляційний суд, інстанція, апеляція.

\section{Summary}

Ostrohliad $0 . V$. Proof in the court of appeals (historical journey). - Article.

The purpose of the article is to analyze historically the existence of an appellate review of the decisions of the court of first instance on the territory of Ukraine in different historical periods, in the aspect of proof, and to build on the basis of this possibility of improvement of this institute in modern conditions. The study is devoted to the historical analysis of the institute of appeal review of decisions of the court of first instance. The main provisions of the development of the appeal in Ukraine. It is noted that the institution of appeal review was inherent in the Ukrainian lands for a long time, and the institution of cassation as a second instance was a temporary phenomenon. The features of evidence are analyzed, due to this particular stage of the proceedings. Knowledge of the history of the existence of this institution allows us to improve it at the present time. It is found that the validity of a court decision is impossible without the exercise of the right of the person concerned to review it by another court. Moreover, such a composition of the court, which is a collegial, independent of the court ruling the contested decision, and which without sending the case to the same court can itself annul the previous decision and, having examined the necessary circumstances of the case, decide its final. Such a procedure for reviewing court decisions is called appellate. Due to its reliability, it is inherent in most countries of the world and serves as an additional guarantee of respect for human rights and avoidance of judicial error. It was emphasized that an appeal or protest had suspended the execution of the sentence, but only in so far as it had been challenged. Against a complaint filed by one party, the other party could file its objections or explanations to the compulsory member of the peace congress (if the case was considered by a magistrate) and to the court (when appealing the decisions of general court rulings), where the case itself was appealed consideration. It is concluded that the common ground of appeal is that provisions not investigated in the court of first instance are not reviewed, except if the participants made such a request during a preliminary trial by a local court or became aware of it after the trial adjudication, as well as the process of proving, is limited by the appeal requirements (although there have historically been moments of full review).

Key words: court, appeal review, evidence, court of appeal, court, appeal. 